\title{
A Legal Framework for Sustainable Electrical Energy Industry in Nigeria
}

\author{
Mercy O. Erhun ${ }^{1} \&$ Daniel O. Johnson ${ }^{2}$ \\ ${ }^{1}$ Department of Public Law, Faculty of Law, Obafemi Awolowo University, Ile-Ife, Nigeria \\ ${ }^{2}$ Department of Electrical and Electronic Engineering, The Federal Polytechnic, Ede, Nigeria \\ Correspondence: Mercy O. Erhun, Department of Public Law, Faculty of Law, Obafemi Awolowo University, Ile- \\ Ife, Nigeria. Tel: 234-803-738-2203. E-mail: pleasantdaniel@yahoo.com
}

Received: July 28, 2018

doi:10.5539/eer.v8n2p45

\author{
Accepted: August 14, 2018 \\ Online Published: November 26, 2018 \\ URL: https://doi.org/10.5539/eer.v8n2p45
}

\begin{abstract}
Nigeria has fairly adequate endowment of energy resources, yet the country is lagging behind in terms of access to reliable and affordable energy supply. The country faces serious challenges as a result of declining electricity generation from domestic power plants. This steady decline has led to a near failure of the electric power sector. Electricity supply required to place Nigeria on the path of economic growth and sustainable development is in very short supply. The country has just 45 electrification rate, with only $54.7 \%$ of her population electrified as at 2016. More than 80 million people are still without access to electricity with frequent power failure. This has contributed to the slow economic growth currently experienced in Nigeria. Regular power supply is the hallmark of a developed economy. Nigeria is blessed with energy resources which could be harnessed to provide various modern energy services and which could have played essential role in the effort to alleviate poverty in the country. There is failure to mobilize the required resources for the development of energy resources in Nigeria. Around $1,500 \mathrm{MW}$ of Nigeria's hydropower potential is currently being used, contributing to about $30 \%$ of the total amount of electricity produced. The large amount of gas associated with oil exploration operations is being wasted through flaring instead of being valuably used for power generation and industrial processes. Current patterns of production and consumption of energy are not sustainable. This paper highlights the importance of sustainable electric energy development in attaining sustainable development in Nigeria.
\end{abstract}

Keywords: legal framework, sustainable development, electrical energy

\section{Introduction}

Nigeria is blessed with energy resources (Note 1) which could be used to harness and to provide various modern energy services and which has been made to play essential role in the effort to alleviate poverty though-out the country. Electricity is an indispensable building block and driving force for economic growth and development. Electricity is a fundamental form of energy which occurs naturally or produced. (Note 2) Electricity generation, transmission and distribution are key indices for measuring or predicting a nation's economic growth. This accounts for the increasing role of government in promoting the development of the electric sector. (Note 3)

Modern energy services are needed to provide access to better medical facilities for maternal care and increased care as well as help to open up opportunities for employment and income generation for the poor. Lighting in schools allows access to educational media and communications in schools thereby improving the quality of education. Provision of modern energy services for irrigation helps increase food production and access to better nutrition and this in turn open up opportunities for employment and income generation.

Energy plays a central role in improving the life of poor people across the world (Note 4) and achieving the goals of sustainable development. The use of modern energy sources is strongly correlated with economic growth as well as human development in the area of health, education and life expectancy etc. Access to energy is therefore critical to economic and social development as well as poverty alleviation. For the economy of any nation to grow, the power sector must be invested upon and made to function optimally. Constant and uninterrupted power supply is the hallmark of a developed economy (Note 5) In contrast, Nigeria is faced with power rationing and frequent shedding. 


\section{Energy}

Nigeria's Energy Resources include fossil fuels, (Note 6) hydroelectricity, uranium, and other renewable energy sources. (Note 7) The world "energy" is defined (Note 8) as "the capacity of objects or systems to do work." Energy can be in the form of electrical energy, nuclear energy, solar energy, thermal energy and petroleum energy. (Note 9) Energy helps to create jobs, develop industries, enhance value added economic activities as well as support income generating activities. Interruption of energy supply can cause serious economic, social and financial loses. Energy is essential to economic dimension of sustainable development. The focus of this study is on electric energy. Electricity is essential to modern productive activities. It has been observed (Note 10) that lack of access to modern energy carriers constraints opportunities to earn income and live healthy lives.

Nigeria is faced with power rationing and frequent load shedding, leading many industries and businesses to loose their competitiveness through purchasing and operating private generators. Paying attention to the energy sector is critical in reducing long term dependence on imported oil and has the ability to lower national debts, thereby improving economic conditions to the benefit of the poor. Access to electrical energy services facilitates economic development in the area of increased productivity, income generation, and locally owned businesses creating employment in local energy service provision and maintenance. Present generation hold the environment and its resources in trust for future generations. (Note 11) Energy must therefore be made available at all times in sufficient quantities and at affordable prices to support the goals of sustainable development.

Access to electrical energy is an important dimension of poverty eradication. Electricity is directly related to issues of poverty reduction (Note 12) and access to basic human needs (Note 13) require appropriate and sustainable energy supply to be developed. Electric energy services are needed to provide access to better healthcare facilities. (Note 14) The energy use patterns of the poor keep them in a perpetual poverty cycle. Improving access to adequate, reliable and affordable modern energy services for the poor is the most appropriate way of addressing these needs and concerns. It will help to reducing poverty and diseases, to achieve universal primary education. It takes a sustainable energy sector to avoid social dysfunction and ensure social and cultural well-being.

\section{History of Electric Power in Nigeria}

Electricity was first produced in Lagos, Nigeria in 1896 while the first generating power plant was established in Lagos in 1898. The Nigerian Government Electricity Undertaking was established -in 1946 under the jurisdiction of the Public Works Department, to take over the responsibility of electricity supply in Lagos. The pattern of electricity was in the form of individual electricity power undertaking, scattered all over towns, while other bodies (Note 15) had licenses to produce electricity in some locations in Nigeria. In 1951, Electric Corporation of Nigeria (ECN) was established as a statutory public corporation to take over power generation projects from Native Authorities. ECN was responsible mainly for the distribution and sales of electricity.

The Niger Dams Authority (NDA) was established in 1962 as an autonomous entity, charged with the responsibility for the provision of hydropower and to construct and maintain dams and other works on the River Niger and elsewhere and to generate electricity by means of water power, improving navigation and promoting fish brines and irrigation. (Note 16) It was charged with the responsibility of building and running generating stations and transmission lines. Both the ECN and the NDA were merged in 1972 to form the National Electric Power Authority (NEPA), with the hope of more effective utilization of the human, financial and other resources available to the electric industry throughout the country.

NEPA became virtually the sole provider of electricity throughout Nigeria to the exclusion of all other organizations. (Note 17) NEPA was given the statutory mandate of developing and maintaining an efficient coordinate and economical system of electricity supply throughout the country. (Note 18) NEPA was privatized in order to ensure that Nigeria has an electric power industry that can meet the needs of its citizens in the 21 st century. (Note 19) The Electric Power Reform Act was put in place to give legal backing to the reform activities (Note 20) in the power sector. The Reform was aimed at improving the overall efficiency through restructuring, private sector participation and competition through improved customer satisfaction and reduced tariff. The main ingredients of the Reform are deregulation, commercialization, free market economy etc. (Note 21)

\section{Sustainable Development}

Sustainable development is an approach to the continued economic development of the world which balances equally the three pillars of sustainable development. (Note 22) Sustainable development calls on global development to consider both the economic advantages and costs of development (Note 23) as well as the impacts of development on all three pillars, and consider the impact of development on the ecosystems, which also relates to human health and well-being. (Note 24) 
Energy represents a major part of sustainable development, which is intended to help humans shift their focus from short-term gain with negative long-term results, to long term gains that can begin to work in the favour of man. Sustainable development is an attempt to create a new bottom line in which value can be seen in the long term, and in which human well-being at present and generations to come are calculated, along with corporate and governmental economic figures into the bottom line. In a sustainable world society, the social, economic and environmental dimensions of sustainable development are integrated into the policy-making process at every level of governance.

Sustainable development is the development that meets the needs of the present without compromising the ability of future generations to meet their own needs. (Note 25) It is a balance between environmental protection and human economic development and between the present and future needs. It means equity in development and sectoral actions across space and time. It requires integration of economic, social and environmental approaches towards development. Sustainable development is development with no damage. (Note 26) Sustainability means enough for all forever. (Note 27) According to John Ehrenfeld, (Note 28) sustainability is the possibility that human and other forms of life on earth will flourish forever.

The Johannesburg Declaration created a collective responsibility to advance and strengthen the interdependent and mutually reinforcing pillars of sustainable development (Note 29) at all levels. (Note 30) The basic idea behind the concept of sustainable development is people, habitats and economic systems. There is therefore the need to consider the three pillars of sustainable development together namely society, economy and environment, when engaging in the generation and distribution of electricity that will be sufficient and available for all on a long term basis without causing damage to human and other forms of life.

Sustainable development is both a conceptual framework, a process as well as an end goal. As a conceptual framework, Sustainable development is a way of changing the predominant world view to one that is more holistic and balanced. As a process, it is a way of applying the principles of integration across space and time to all decisions and as an end goal, it is used to identify and fix the specific problems of resource depletion, health care, social exclusion, poverty, unemployment etc.

Since the Earth summit which took place at Rio, the concept of sustainable development has been placed on national and international policy agenda and there have been efforts since then to operationalize sustainable development by governments, international organizations, local authorities, business, citizen groups and individuals. Several challenges threaten progress towards the attainment of sustainable development goals. These problems are mostly rooted in issues of resource use and their pattern of distribution and ownership.

The goals for sustainable human development are listed (Note 31) as poverty reduction, universal education, gender equality, reproductive health and environment. The principles of sustainable development as listed by Dipakde et al (Note 32) are holistic development, development within the boundary of environment, development within socio-cultural and traditional - knowledge base, enhanced quality of life, the promotion of collectiveness, needs of future generations, global diversity, people's participation and empowerment to manage their surrounding and natural resources, development based on national policy and needs and one that encourages least energy and judicious use of resources.

\section{Energy and Sustainable Development}

Access to energy facilitates the eradication of poverty and improved access to reliable and affordable energy services for sustainable development. It is a means of generating other important services that mitigate poverty. Energy is essential to economic and social development and improved quality of life. The principle of sustainable development encourages least and judicious use of energy resources. Energy must be used in a way that is consistent with the aim of protecting human health, the atmosphere and the natural environment, if it is to be sustainable. Environmentally sound energy approaches are necessary to control atmospheric emissions of greenhouse and other gases and substance. (Note 33) Increased access to energy will generate opportunities for economic growth, enhance education, better health care, more training and employment as well as higher productivity in business, thereby contributing to sustained poverty reduction.

It takes sustainable energy sector to avoid a degraded environment associated with the challenges of poaching, environmental degradation, soil erosion etc., and to ensure environmental integrity that will ensure a sustainable and healthy environment as well as pollution prevention and control. Sustainable energy sources mean that which will allow the earth to sustain a balanced, healthy ecosystems and human life. Sustainable energy is defined (Note 34 ) as energy that is capable of meeting the needs of present generation without compromising the ability of future generations to meet their own energy needs. Sustainable energy is energy which is produced and used in ways that support human development over the long term, in all its social and economic environmental dimensions. (Note 
35) Examples of sustainable energy sources include solar energy, wind energy, some forms of hydro power like micro-hydro power which are not disruptive to the natural environment, hybrid-electric cars which make use of more gas and less fuel and emit much less carbon monoxide, nuclear power and some biomass fuels. More concrete steps should be taken to ensure sustainable electric supply in Nigeria. Well designed hydropower projects can be developed in an environmentally friendly, socially responsible and economically viable manner.

Sustainable development is defined as a development that meets the needs of the present, without compromising the ability of future generations to meet their own needs. (Note 36) It requires meeting the basic needs of all and extending to all the opportunity to satisfy their own aspirations for a better life. Sustainable development is a process of change in which the exploitation of resources, the direction of investments, the orientation of technological development and institutional change are in harmony and enhance both current and future potentials to meet human needs and aspirations. In a sustainable world society, the social, economic and environmental dimensions of sustainable development are integrated into the policy-making process of the energy sector at every level of governance. In the light of the discussion on energy, this means that future generations will have the services provided by energy. This requires efficient extraction and use of existing energy resources while developing new forms of energy and associated technologies over the longer term, with emphasis on how to ensure the continuous available of energy.

The production and use of energy represents a major source of environmental degradation, having a single most severe threat to sustainable development. Indoor pollution and carbon emission constitute threat to human health. Access to cleaner, more efficient fuels will reduce greenhouse gas emissions which are a major contributor to climate change. The combustion of fossil fuels (Note 37) used to power industries, transportation and electric power plant is the post important source of emission of greenhouse gases. Electric power production from large coal, oil and gas, if not designed in an environmental friendly, socially responsible and economically viable manner, is also a source of concern. Energy production from large hydroelectric dams is also a source of concern. Efficient use of energy helps to reduce local pollution and improve conditions of the poor. The sustainable energy for all initiative was launched in 2011, with the aim of proving universal access to modern energy, double the global rate of improvement in energy efficiency and double the share of renewable in the global energy mix by the year 2030 . Unfortunately, as observed by Atsegbua et al, (Note 38) there is no detailed and comprehensive policy for renewable energy in Nigeria.

\section{Regulatory Regime for the Nigerian Power Sector}

\subsection{The Constitution of the Federal Republic of Nigeria}

SAs stated under the economic objectives of Nigeria, the State shall harness the resources of the nation and promote national prosperity, and an efficient, a dynamic and self reliant economy; (Note 39) control the national economy in such manner as to secure the maximum welfare, freedom and happiness of every citizen on the basis of social justice and equality of status and opportunity; (Note 40) manage and operate the major sectors of the economy; (Note 41) and protect the right of every citizen to engage in economic activities. (Note 42) The State also pledged to direct its policy towards ensuring the promotion of a planned and balanced economic development; (Note 43) that the material resources of the nation are harnessed and distributed as best as possible to serve the common good; (Note 44) that the economic system is not operated in such a manner as to permit the concentration of wealth or the means of production and exchange in the hands of few individuals or of a group; (Note 45) and that suitable and adequate shelter, suitable and adequate food, reasonable national minimum living wage, old age care and pensions, and unemployment, sick benefits and welfare of the disabled are provided for all citizens. (Note 46) The fulfillment of these objectives requires a sustainable electric power supply that will keep production going without any form of hindrance. Unfortunately, the reverse is the case in Nigeria.

\subsection{The Electric Power Sector Reform Act 2005}

The above Act led to the transition of National Electric Power Authority to the Power Holding company of Nigeria. The Act was enacted on March 11, 2005, with the objective of ensuring private sector participation, and bringing about a competitive power market in place of monopoly market earlier dominated by NEPA, (Note 47) and fasttracking the restructuring and privatization of the sector. The Act therefore made provision for the development of a competitive electricity market.

The Electric Power Sector Reform Act is saddled with the responsibility of providing uninterrupted electricity. It is also has the responsibility of ensuring safe, adequate, reliable and affordable services in the generation, transmission, distribution and trading of electricity, (Note 48) to ensure private sector participation, to protect the interest of the consumers, to monitor the health and safety regulations by electricity companies to make fair regulations and ensure vigilant over-sight of the electric industry and been firm in the enforcement of rules and 
regulations. (Note 49)

The Electric Power Sector Reform is expected to improve the stability of electricity supply, improve cost recovery, increase the availability of investment capital, usher in competitive energy market and provide jobs for the populace. The Reform also poses some political challenges like the construction of plants within the Niger Delta area which has unfriendly political climate, (Note 50) environmental, technical challenges as a result of the high carbon monoxide emission already witnessed in Nigeria from chemical industries, economic and social challenges like the generation of more electricity. (Note 51)

\subsection{The Nigerian Electric Regulatory Commission (NERC)}

The Nigerian Electric Regulatory Commission was established by the Electric Power Sector Reform Act (EPSRA) to ensure effective implementation of the goals and objectives of the Electric Power Reform Act. Its function is to regulate and monitor the Nigerian Electricity Industry. (Note 52) The mission of the Commission is to promote and ensure an investor friendly industry and efficient market structure to meet the needs of Nigeria for safe, adequate, reliable and affordable electricity. Its vision is to "keep the lights on" by providing electricity on demand. (Note 53) The establishment of NERC is pivotal in making the Power Sector Reform a reality.

\subsection{Electric Power Implementation Committee}

The above is a steering Committee put in place to carry out the functions of synchronizing, coordinating and monitoring all activities relating to the reform, restricting and privatization of the electric power sector, and to formulate proposals for the creation of conditions that will help to sustainably develop the power sector.

\subsection{The Federal Ministry of Energy}

The above Ministry is concerned with the formulation of policies for electric power, including the policy on renewable electricity. The Ministry is responsible for the promotion, monitoring, evaluation and assessment of policy implementation of renewable energy utilization in Nigeria.

\subsection{Energy Commission of Nigeria}

The Nigerian Energy Commission is saddled with the responsibility of conducting strategies, planning and coordination of all national policies in the energy sector, with a view to ensuring that the sector is of benefit to government, citizens as well as private companies in an environmentally responsible manner.

\section{Barriers to Environmentally Friendly and Sustainable Electric Energy Production}

The provision of electricity in an environmentally friendly manner in Nigeria has been hindered as a result of the following reasons:

\subsection{Poor Maintenance Culture}

Domestic power plants are dilapidated, obsolete and in appalling state of disrepair. This a reflection of the poor maintenance culture in Nigeria and gross inefficiency of the public utility provided.

\subsection{Lack of Adequate Framework to Regulate the Energy Sector}

One of the challenges of the electrical sector is the establishment of an effective and transparent licensing framework that will attract potential investors, while still able to ensure best practices in industry, standards and codes are enshrined to protect the interest of consumers and other stakeholders. (Note 54) Nigerian energy policies are deficient to ensure sustainable electric energy supply as the country does not carry out frequent review of her energy policy. Nigeria lacks adequate legal, policy, institutional and regulatory framework to address her electrical energy problems and the private sector has not be effectively mobilized to participate in the operation and management of the electricity sector of Nigeria. The Nigerian Electricity Regulatory Commission is faced with the challenge of providing a licensing framework to enable independent power producers interested in investing in the generation of power in Nigeria to commence operations. As a result, Nigeria's energy policies do not adapt to the reforms to the reforms taking place all over the world in the global energy sector.

\subsection{Lack of Competitive Electricity Market}

Despite the provision for a competitive electricity market by the Electric Power Sector Reform Act, private companies are hesitant to come into the electricity market because of fear of not been able to make their profit before the end of the ten year maintenance check as provided in the Electric Power Reform Act. (Note 55)

\subsection{Lack of Access to Reliable and Affordable Energy Services}

Lack of access to reliable and affordable electricity services is a very critical challenge facing Nigeria presently. It takes efficient use of modern forms of energy to realize the potentials for creating wealth and to lift the Nigerian 
population out of poverty. Improved access to modern electric power services is important in order to help Nigerians escape from the vicious cycle of poverty.

\section{Framework for Sustainable Energy Sector in Nigeria}

A framework that will ensure that all the dimensions of sustainable development are integrated at all levels of governance in Nigeria includes the following:

\subsection{The Establishment of an Adequate Institutional, Policy, Legal and Regulatory Framework}

Legal measures in promoting electric energy for sustainable development are very important if sustainable electric energy is to be realized. Adequate institutional structures as well as a strong and effective legal and regulatory framework that would help create conducive environment for private sector participation in the development, operation and management of the energy sector is very important. Adequate attention should be given to the development of appropriate legal and regulatory structures with enforcement mechanisms which will provide clear rules of the game for all players and define the responsibilities and obligations as well as protect business and investor interests while safe-guarding the public and consumers. Such regulatory measures should discourage provisions for subsidies so as to enhance the revenue base in Nigeria.

\subsection{Environmental Impact Assessment Act}

Environmental impact assessment of any operation in the electric power sector is a very important tool for the promotion of sustainable electrical energy sector. Such a measure will require all federal actions which are likely to significantly affect the quality of human environment in the Nigeria. Capital projects in electricity sector can to be subjected to environmental impact assessment. Citizens should be empowered with the locus standi to challenge project which fail to conform to the provisions of the Act in court. Consequently, the consequences of any proposed action can be adequately considered before they are implemented.

\subsection{Financing for Sustainable Electric Energy Development}

Financing electric energy for sustainable development is a crucial element of the challenges posed by the implementation of Agenda 21. (Note 56)Investment in the development of electric energy resources is capital intensive. A framework that will dispel the perception of high risk associated with private investment in Nigeria is necessary in order to attract private investors into the energy sector. Mobilization of financial resources to tackle the challenge of electric energy for sustainable development is very important if the goals and objectives of sustainable electric energy production and consumption is to be achieved. Access to modern electric energy services is an important pre-condition for the eradication of poverty. A robust framework for sustainable development finance (Note 57) as well as an environment conducive for business are needed. With the above, capital flows and portfolio investment can be channeled to the sustainable electric energy development agenda, to eliminate illicit financial flows, to enhance the regulation of secrecy jurisdictions and to promote asset recovery. Multilateral development banks can help to identify novel sources of sustainable electric energy development financing. The financing framework will also require the mobilization of domestic resources. This could be by broadening the tax base and improving tax administration and improving corporate and public governance of extractive industries in Nigeria. It has been opined (Note 58) that private sector capital investment in sustainable electric energy will materialize only when investment opportunities are perceived as yielding high risk adjusted net returns on the relevant investments.

\subsection{Renewed Partnership and Means of Implementation}

A renewed partnership (Note 59) for sustainable development is essential for the realization of the new development agenda in the Nigerian electric energy sector. A partnership to mobilize means of implementation and a participatory monitoring framework for tracking progress and mutual accountability mechanisms for all stakeholders of the electric energy sector are necessary building blocks for the realization of this vision of sustainable electric energy. The Post-2015 Development Agenda on the provision of affordable and clean energy, is to ensure access to affordable, reliable, sustainable and modern energy for allwill have to be support by a renewed multi-stakeholder partnership that respond to the sustainable development agenda and grounded on the values of equity, solidarity and human rights. The multi-stakeholder partnership could be within governments, businesses, private philanthropic foundations, international organizations, volunteer groups, local authorities, the legislature, trade unions, research institutions and the academia. Such partnership can channel commitments and actions from a wider set of actors in the electric sector.

\subsection{A Comprehensive Monitoring Framework}

Effective implementation of the Post-2015 Development Agenda on the provision of affordable, sustainable and 
clean energy for all requires effective monitoring and accountability mechanisms. This can be through the use of direct citizen engagement as well as ensuring that operations in the electric sector make use of new technologies, thereby ensuring that activities in this sector are carried out in a responsible and environmentally friendly manner.

\section{Conclusion}

The world quest for dignity, peace, prosperity, justice, sustainability and an end to poverty has reached an unprecedented moment of urgency. The tasks of the MDGs in achieving significant improvement in the lives of people remain uncompleted. This task needs to be completed in order to secure the well-being, dignity and the rights of all those still on the margin today, as well as those of future generations. A new era demands a new vision and a responsive framework. Special attention is needed as the world is making the transition to an agenda that embraces sustainable development.

Sustainable development is the part way to the future. Sustainable development, enabled by the integration of economic growth, social justice and environmental stewardship must be made the global guiding principle and operational standards in the Nigerian electric power sector. This is the only framework that can bring together the full range of human aspirations and needs. It is a framework that offers a template for mutually reinforcing approaches to overcoming the challenges of providing sustainable electric energy in Nigeria.

Nigeria has enough for the need of everyone, but not for the greed of the greedy. In a nation highly favoured with great wealth, no person anywhere should be left behind and no one should go hungry or lack basic human amenities which are the foundation for a decent life and none should be made to face social and economic exclusion or live without access to basic services such as electricity. It takes a sustainable energy sector to avoid social dysfunction and ensure social and cultural well-being. We must all join faith together in strengthening and building collaboration and building the just, prosperous and sustainable world that people desire, and in building a future of justice and a life of dignity for all by ensuring the provision of sustainable electric power supply for all.

\section{Recommendations}

A robust electric energy sector is necessary to enhance sustainable economic growth. Policy measures and appropriate actions aimed at overcoming barriers to sustainable electric energy production and consumption needs to be adopted. An adequate and attractive institutional, legal, policy and regulatory framework that will attract private capital and managerial resources in the energy sector needs to be put in place.

The world is witnessing the replacement of command and control measures with market mechanism in the promotion of sound energy policies. This is to ensure that a level playing field is created for resources in the market place. All necessary ingredients to attract private investors in this sector should be put in place.

Sustainable development is the process of judicious use and conservation of natural resources for the overall improvement in the quality of life for the present and future generations on long term basis. Nigeria's electric power sector requires substantial reform if the nation's economic development and poverty alleviation is to be realized, and in order to enthrone sustainable electric sector and by extension, sustainable development. Resources in the electric power sector must be judiciously used and conserved for the benefits of present and future generations if sustainable development is to be attained.

Government through its agency regulates providers and distributors of electricity. Government should give the private sector transparent incentives to provide electrical energy with sustainable business practice. Electricity contracts can be awarded not only to the lowest cost provider, but also to a company that will provide electricity on the most environmental friendly manner. It takes sustainable energy to solve the problem of greenhouse gas emissions.

Government must be determined to reduce inefficiencies in the way electric energy resources are extracted and converted in order to ensure that the harnessing ofelectric energy resources contributes significantly to sustainable development. Finance for sustainable electric energy can be mobilized from Multilateral Development Banks who can be approached to assist in this regard. Private and Public sector investments can also be enhancedby broadening the tax base and improving tax administration. Improved corporate and public governance of extractive industries in Nigeria can also be relied upon. This will go a long way in attracting capital flows for sustainable electric energy supply.

In order to overcome the challenges of sustainable development, environmental issues must be addressed by focusing on the provision of sustainable electric energy in an environmentally friendly manner and one that will enable future generations to meet their own needs. In this regard, electrical energy needs of Nigeria must be considered when planning energy supply if Nigeria is to meet energy demand for members of her households more efficiently and in a cost-effective manner. There must also be commitment by both the public and private scientific 
and research communities to develop new and transformative technologies.

A competitive electricity market is necessary in order to help create a healthy rivalry among the different companies where expertise rather than mediocrity would be promoted. The full implementation of the Electric Power Reform Act will go a long way in ensuring sustainable electric power supply in Nigeria. This should be improved upon in Nigeria.

Nigeria can benefit immensely from the development of her hydropower and natural gas for the production of commercial energy supplies required for her social and economic development in an environmentally sound manner by harnessing available energy resources to ensure the provision of commercial supplies necessary to fuel economic growth and poverty reduction should rank high in Nigeria's policy agenda.

\section{References}

Adoghe, A. U. (2004). Effects of Electric Power Supply Reliability and Stability in Nigeria.

Advisory Power Team. (2015). Nigeria Power Baseline Report Office of the Vice President, Federal Government of Nigeria.

Atsegbua, L., Akpotaire, V., \& Dimowo, F. (2010). Environmental Law in Nigeria, Theory and Practice. Ambik Press, Benin City

Campos, J. E., \& Salehi-Esfahani, H. (1996). Why and When Do Governments Initiate Public Enterprise Reforms? World Bank Economic Review, 10(3), 451-485. Dipakde and Basavaprabhu Jirli, Environment and Sustainable Development Concept, Model and Principle. Available at: http://agropedia.iitk.acin/openaccess/sites/default/files/WS\%201.pdf.

Helen Obioma Onyi-Ogelle (2016). The Implications of Legal Reform in the Nigeria Power Sector. Africa Research Review, 10(3), Serial No.42.

Inugonum, T. (2005). Challenges Facing the Development of Independent Power Producers in the Deregulated Power Sector in Nigeria (NEPA as case study). $6^{\text {th }}$ International conference on Power System Operation and Planning (ICPSOP) pp 33-37.

Latham \& Watkins (2016). Africa Practice Nigerian Power Sector: Opportunities and Challenges for Investment.

Vinveeta, S. (2014). An Impact and Challenges of Sustainable Development in Global Era. Journal of Economics and Development Studies, 2(2).

Nnaemeka, V. E., \& Samson, D. Y. (2015). Improving Electricity Access in Nigeria: Obstacles an the Way Forward. International Journal of Energy Economics and Policy, 5(1), 335-351.

Okoro, O. (2007). Power Sector Reforms in Nigeria: challenges and Opportunities. Journal of Energy in Southern Africa, 18(3).

Thomas, B. J. (2005). The Imperatives of Energy For Sustainable Development in Adrain, J. Bradbrook, Rosemary Lyster, Richard L. Ottinger and Wang XI (eds.) The Law of Energy For Sustainable Development, Cambridge University Press, Cambridge

Weisse, B. E. (1990). Our Rights and Obligations to Future Generations for the Environment 84 AJIL 198 at 199.

Rosmemary, L., Richard, L., Ottinger \& Wang, X. I. (2005). Worika, Ibibia Energy Development and Utilization in Africa in Adrian J. Bradbrook, The Law of Energy for Sustainable Development, Cambridge University Press, Cambridge.

Yergin, D. (1991). The Prize: An Epic Quest for Oil, Money and Power. Simon \& Schuster Ltd.

\section{Notes}

Note 1. Such as oil, gas, coal, hydropower etc

Note 2. Electricity, Definition of Electricity available at http://www.merriam-webster.com/dictionary/electricity>

Note 3. Wikipedia "Deregulation" available at $<$ http://en.wikipedia.org/wiki/Deregulation

Note 4. World Summit on Sustainable Development

Note 5. Okoro, O. (2009) "Power Sector Reforms in Nigeria: Challenges and Opportunities" p. 1

Note 6. Such as oil, natural gas and coal

Note 7. Such as solar, geothermal energy, wind etc. 
Note 8. Oxford World Encyclopedia (1998) Oxford University Press, Oxford, U.K. at 471

Note 9. Yergin, D. (1991) “The Prize: An Epic Quest for Oil, Money and Power, Simon \& Schuster Ltd.

Note 10. Thomas B. Johansson (2005) "The Imperatives of Energy For Sustainable Development" in Adrain, J. Bradbrook, Rosemary Lyster, Richard L. Ottinger and Wang XI (eds.) (2003) The Law of Energy For Sustainable Development, Cambridge University Press, Cambridge pp 46-52

Note 11. Weisse, Brown E. (1990) "Our Rights and Obligations to Future Generations for the Environment" 84 AJIL 198 at 199

Note 12. This is in the area of health, income generation, food, water and habitat systems

Note 13. Such as food, shelter, health care, education, access to information and employment.

Note 14. This includes lighting operating theatres, refrigeration of vaccines and other medicines, sterilization of equipment and transport to health centres etc.

Note 15. Such as Native Authorities (who carried out their operations through the Public works Department) and the Nigerian Electricity Supply Company

Note 16. Lawal, T.A. et al "Energy and Power Generation, Transmission and distribution in Lagos State available at http://wwwcefolassaocoed.net/index/php?option $=$ com_content\&view $=$ article\&id $=83 \& 1$ ltemid $=88 \&$ limistart $=3$

Note 17. See Section 1(1) of the National electric Power authority (NEPA) 1990 Act Cap. 256, LFN

Note 18. See Section 1(1) of the National electric Power authority (NEPA) 1990 Act Cap. 256, LFN

Note 19. Chudi Nelson "Road Map to the Reform of the Electric Power Sector

Note 20. Such as restructuring and eventual privatization of NEPA

Note 21. Campos, J. E. and Salehi-Esfahani, H. "Why and when do governments Initiate Public Enterprise Reforms" World Bank Economic review 1996 Vol 10 Is 3 at p. 451

Note 22. These are the economic, social and environmental pillars of sustainable development

Note 23. This includes the processing to help bridge the gaps in the economic status of people in all the communities of the world

Note 24. This touches on jobs, health and over-all quality of life

Note 25. World Commission on Environment and Development

Note 26. Ms. Vinveeta Sing (2014) "An Impact and Challenges of Sustainable Development in Global Era," Journal of Economics and Development Studies, Vol. 2, No. 2, pp 327-337 at 330

Note 27. African Delegate to Johannesburg (Rio+10)

Note 28. John Ehrenfeld is Professor Emeritus, MIT

Note 29. Such as the economic pillar, the social pillar and the environmental pillar of sustainable development.

Note 30. Such as global, regional, national and local levels

Note 31. The United Nations, the World Bank and the Organisation for Economic Cooperation and Development (2012b) Back to Our Common Future. Sustainable Development in the $21^{\text {st }}$ Century (SD21) Project: Summary For Policy Makers, Department of Economics and Social Affairs, Division of Sustainable Development, New York

Note 32. Dipakde and BasavaprabhuJirli "Environment and Sustainable Development Concept, Model and Principle available at http://agropedia.iitk.acin/openaccess/sites/default/files/WS\%201.pdf.

Note 33. Agenda 21

Note 34. Worika, Ibibia (2005) "Energy Development and Utilization in Africa" in Adrian J. Bradbrook, RosmemaryLyster, Richard L. Ottinger and Wang X I (2005) The Law of energy for Sustainable Development, Cambridge University Press at p. 327

Note 35. UICN Commission on Environmental Law and its Climate and Energy Working Group, "Brainstorming Session in the World Energy Assessment and Sustainable Energy Outreach" 2003

Note 36. The Brundtland Commission

Note 37. Such as oil, coal, natural gas

Note 38. Atsegbua, L., Akpotaire, V. and Dimowo, F. (2010) Environmental Law in Nigeria, Theory and Practice, 
Ambik Press, Benin City at p. 304

Note 39. Section 16(1)(a) of the Constitution of the Federal Republic of Nigeria

Note 40. Section 16(1)(b) of the Constitution of the Federal Republic of Nigeria

Note 41. Section 16(1)(c) of the Constitution of the Federal Republic of Nigeria

Note 42. Section 16(1)(d) of the Constitution of the Federal Republic of Nigeria

Note 43. Section 16(2)(a) of the Constitution of the Federal Republic of Nigeria

Note 44. Section 16(2)(b) of the Constitution of the Federal Republic of Nigeria

Note 45. Section 16(2)(c) of the Constitution of the Federal Republic of Nigeria

Note 46. Section 16(2)(d) of the Constitution of the Federal Republic of Nigeria

Note 47. Nigeria Village Square: "Nigeria's Electric Power Sector Reform: Matters Arising" available at $<$ http://www.nigeriavillagesquare.comarticles/shokos-mixed-bag/nigerias-electric-power-sectorreform

Note 48. Nigerian Electricity Regulatory commission (NERC) Nigerian Electricity Regulatory commission; Goals and $\quad$ Objectives. Available at $<$ http://www.nercng.org/index.php\%3Foption\%3Dcom_content\%26task\%Dview\%26id\%3D51\%261temid\%3D2 9>

Note 49. Centre for Social Justice, "Power Sector Reforms available at <http://www.csjng.org/programspower.php>

Note 50. Adoghe, A. U. (2004) "Effects of Electric Power Supply Reliability and Stability in Nigeria p. 6

Note 51. Inugonum, T. "challenges Facing The Development of Independent Power Producers in the Deregulated Power Sector in Nigeria (NEPA as a Case Study). Paper Presented on the 6th

Note 52. Mbendi Information Services "The Licensing process"

Note 53. Nigerian Electric Regulatory Commission (NERC) "Nigerian Electricity Regulatory Commission: Mission and Vision."

Note 54. Nigerian Society of chemical Engineering (NSCHE) 2005, “The Role of Independent Power Project (IPP) in Meeting Power Demands in Nigeria

Note 55. See Section $25-30$ of the Electric Power Reform Act 2005

Note 56. JavaraoGururaja "Financing Energy for Sustainable Development" pp 222-230

Note 57. Such sustainable development finance can be from both private and public funding.

Note 58. JavaraoGururaja supra

Note 59. Such a partnership can be patterned after the Busan Partnership for Effective Development Cooperation, but tailored to meet the exigencies of this nation.

\section{Copyrights}

Copyright for this article is retained by the author(s), with first publication rights granted to the journal.

This is an open-access article distributed under the terms and conditions of the Creative Commons Attribution license (http://creativecommons.org/licenses/by/4.0/). 